\title{
Growth, gas exchange and carbon isotope discrimination in young Prunus avium trees growing with or without individual lateral shelters
}

\author{
C Collet 1, A Ferhi 2, JM Guehl 3, H Frochot 1 \\ 1 INRA, centre de Nancy, laboratoire Lois de Croissance, F-54280 Champenoux; \\ 2 Centre de recherches géodynamiques, université Paris VI, 47, avenue de Corzent, \\ F-74203 Thonon-les-Bains; \\ 3 INRA, centre de Nancy, laboratoire de Bioclimatologie et d'Écophysiologie forestières, \\ F-54280 Champenoux, France
}

(Received 3 November 1992; accepted 5 February 1993)

\begin{abstract}
Summary - One-yr-old wild cherry (Prunus avium $\mathrm{L}$ ) plants were grown as follows: 1 ) in small cylindrical shelters (diameter $50 \mathrm{~cm}$, treatment S); 2) in large shelters (diameter $100 \mathrm{~cm}$, treatment L); or 3) without shelter (control, treatment $C$ ) during 1 growing season. Treatment $C$ was characterized by higher values of photosynthetic photon flux density $\left(I_{0}\right)$ and of leaf-to-air water vapour pressure difference $(\Delta W)$ than treatments $L$ and $S$. The plants were taller in treatments $L$ and $S$ than in treatment $\mathrm{C}$ but biomass production was higher in the latter treatment. The plants of treatment $\mathrm{C}$ were also characterized by higher values of $\mathrm{CO}_{2}$ assimilation rate $(\mathrm{A})$ and of leaf mass per unit area ( $L M A$, ratio of leaf mass to leaf area). Relative carbon isotope composition $\left(\delta_{\mathrm{p}}\right)$ of the leaves was higher in treatment $C$ than in treatments $L$ and $S$, which expresses higher time-integrated values of plant intrinsinc water-use efficiency $(A / g$ ratio) in the former treatment. There was a positive correlation between $\delta_{\mathrm{p}}$ and $L M A$. Thus, $L M A$, a readily measurable parameter, is a relevant parameter for understanding and modelling water-use efficiency of canopies.
\end{abstract}

lateral shelter / microclimate / growth / leaf gas exchange / carbon isotope discrimination / water-use efficiency/leaf mass per unit area

Résumé - Croissance, échanges gazeux et discrimination isotopique du carbone de jeunes merisiers (Prunus avium $L$ ) placés ou non dans des abris latéraux individuels. Des plants de merisier (Prunus avium $L$ ) âgés de 1 an ont été installés durant une saison de végétation dans 1) des petits abris cylindriques (diamètre $50 \mathrm{~cm}$, traitement S); 2) des grands abris cylindriques (diamètre $100 \mathrm{~cm}$, traitement L); ou 3) sans abri en plein découvert (traitement C) (fig 1). Le traitement $C$ était caractérisé par des valeurs plus élevées de rayonnement photosynthétiquement actif (Ip) ainsi que de différence de pression partielle de vapeur d'eau entre feuille et atmosphère $(\Delta W)$ (fig 3). La croissance en hauteur était plus élevée pour les plants du traitement $C$ que pour ceux des traitements $L$ et $S$, alors que la production de biomasse était la plus élevée dans le traitement $C$ 
(tableau I). Les plants du traitement $C$ étaient également caractérisés par des valeurs plus élevées de taux d'assimilation de $\mathrm{CO}_{2}$ (A) (fig 5) ainsi que de masse foliaire spécifique (LMA, rapport de la masse sur la surface foliaire) (fig 8). La composition isotopique relative en carbone $\left(\delta_{\rho}\right)$ des feuilles était plus élevée dans le traitement $C$ que dans les traitements $L$ et $S$ (fig 8). Cela traduit des valeurs intégrées dans le temps d'efficience intrinsèque d'utilisation de l'eau (rapport A/g) plus élevées pour le traitement $C$ (tableau I). On a noté une corrélation positive entre $\delta_{\rho}$ et LMA (fig 8). Ainsi, LMA, qui est une grandeur facilement mesurable, constitue un paramètre pertinent pour la compréhension et la modélisation de l'efficience d'utilisation de l'eau des couverts végétaux.

abri latéral / microclimat / croissance / échanges gazeux foliaires / discrimination isotopique du carbone / efficience d'utilisation de l'eau / masse foliaire spécifique

\section{INTRODUCTION}

The neighbourhood relationships between young trees and the surrounding vegetation are the result of various below-ground (competition for water and nutrients, allelopathy) and above-ground (competition for light, modification of temperature, air humidity and windspeed) interactions (Gjerstad et al, 1984 ; Radosevich and Osteryoung, 1987). When neighbourhood relationships are dominated by competition processes, their global effect will be to reduce survival and growth of the young trees. However, in situations of high potential evapotranspiration, the presence of accompanying vegetation may be beneficial for the trees due to lowered evaporative demand at the tree level.

To analyze the neighbourhood relationships it is necessary to disentangle the effects of aerial and soil factors (Nambiar, 1990). The use of artificial lateral shelters built around growing young trees may be a relevant way of studying the effects of aerial microclimate modifications on the growth and function of plants (Collet and Frochot, 1992). The general effect of lateral shading will be to reduce photosynthetic $\mathrm{CO}_{2}$ assimilation due to lowered leaf incident photosynthetic photon flux density. However, this reduction may be accompanied by a decrease in stomatal conductance and in transpirational water losses which can be beneficial for the plant water status and water-use efficiency (Aussenac and Ducrey, 1978).

This study examines the effects of artificial lateral shelters simulating the aerial effects of an accompanying vegetation without any below-ground relationship - on young Prunus avium trees. Measurements of: 1) microclimatic parameters ; 2) growth ; 3) leaf gas exchange ; and 4) leaf carbon isotope composition which can lead to time-integrated plant water-use efficiency were made.

\section{MATERIAL AND METHODS}

\section{Experimental design}

Wild cherry (Prunus avium L) seedlings (Côte d'Or provenance, Eastern France) were grown in an experimental nursery near Limoges (Massif Central, France) from spring 1989. On February 15 1990, 48 plants (average height $30 \mathrm{~cm}$ ) were taken from the nursery beds. In order to minimize transplanting stress, the plants were immediately placed in containers filled with organic soil and transferred to the experimental plot near Nancy (northeastern France) where they were planted. The trees were randomly distributed into 3 treatments comprised of 16 trees each:

Treatment $S$ (small shelters). These plants were surrounded by individual cylindrical shelters with a diameter of $50 \mathrm{~cm}$. 
Treatment $L$ (large shelters). These plants were surrounded by cylindrical shelters with a diameter of $100 \mathrm{~cm}$.

\section{Treatment C. Controls without shelters.}

The shelters were constituted of a wire netting supporting a green plastic net with a porosity of $50 \%$ (fig 1). Initially, the shelters were 60 $\mathrm{cm}$ high. As the seedlings grew, the height of all the shelters was increased so that no plant was greater than its shelter. Four successive height increases were made simultaneously for all shelters (fig 2). At the end of the growing season the shelters were $2.5 \mathrm{~m}$ high. Bare soil conditions were maintained throughout the experiment by chemical weeding around the shelters and manual weeding within the shelters. Rainfall during the experimental period (April-September) amounted to $262 \mathrm{~mm}$ and no additional water was supplied to the trees.

In order to assess the microclimatic conditions inside the 2 types of shelters, photosynthetic photon flux density $\left(I_{p}\right)$ was measured at 12.00 (solar time) on a sunny day with a quantum sensor (Li-Cor, Lincoln, NE, USA) at different heights above ground. These measurements were made when the shelters were $1.5 \mathrm{~m}$ high. At the top of the shelter Ip was similar to that outside the shelters $(100 \%)$. Below $115 \mathrm{~cm}$ (S shelters) and $75 \mathrm{~cm}$ (L shelters), Io was abruptly reduced to $30 \%$ of the ouside $I_{p}$ in both types of shelters. Thus, the upper parts $(\approx 30 \mathrm{~cm}$ for the $S$ shelters and $40 \mathrm{~cm}$ for the $\mathrm{L}$ shelters) of the elongating stems were exposed to full sunlight around midday while the lower parts were shaded all day long.

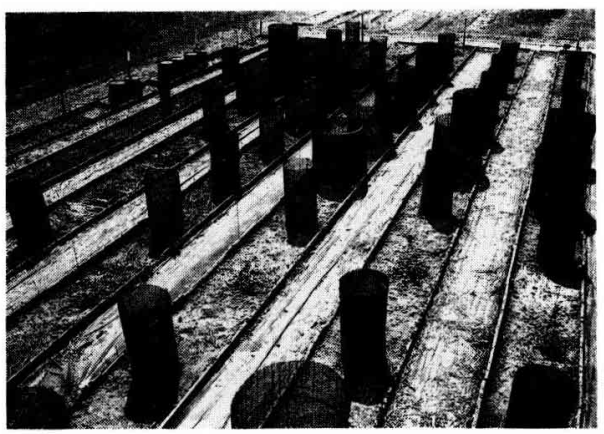

Fig 1. Picture of the experimental plot showing the shelters ( $1 \mathrm{~m}$ high).

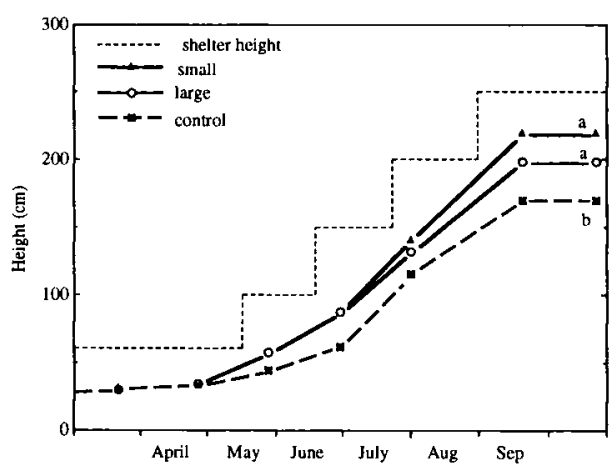

Fig 2. Growth in height in the 3 treatments and height of the shelters. For the last measurement date, data points with different letters are significantly different (Student's $t$-test, $P \leq 0.05$ ).

\section{Water status and gas exchange measurements}

Water status and gas exchange measurements were made periodically between July 11 and August 16. These measurements were carried out on the 6 tallest plants in each treatment in order to avoid experimental interference due to transplanting stress. Predawn leaf water potential of the seedlings was measured with a Scholander pressure chamber and was between $-0.1 \mathrm{MPa}$ (July 11) and $-0.45 \mathrm{MPa}$ (August 16), thus indicating an absence of severe drought constraints.

Carbon dioxide assimilation rate $\left(A, \mu \mathrm{mol} \mathrm{m}^{-2}\right.$ $\left.\mathrm{s}^{-1}\right)$, transpiration rate $\left(E, \mathrm{mmol} \mathrm{m}^{-2} \mathrm{~s}^{-1}\right)$ and leaf conductance for water vapor $\left(g, \mathrm{mmol} \mathrm{m}^{-2}\right.$ $\mathrm{s}^{-1}$ ) were measured using a $\mathrm{LI}-6200$ portable photosynthesis system (Li-Cor Inc, Lincoln, $\mathrm{Ne}$ braska, USA) fitted with a 4-I assimilation chamber. Leaf temperature $\left(T_{1}\right)$ was monitored by means of a thermocouple in contact with the lower leaf surface. The leaf-to-air difference in water vapour partial pressure $(\Delta W)$ was calculated from $T_{1}$ and air water vapour pressure. Simultaneously to the gas exchange measurements, $I_{p}$ was measured with a quantum sensor (Li-Cor, Lincoln, NE, USA). Preliminary measurements were carried out in order to assess the effects of leaf ageing on gas exchange parame- 
ters. $A$ and $g$ were highest for leaf order between 4 and 7 . All gas exchange data reported hereafter correspond to measurements made within that zone of the trees which, in the shelters, was generally at the transition between the shaded and the full sunlight exposed regions. Gas exchange measurements were performed between 11.30 and 13.30 (UT) on 2 leaves per tree. Gas exchange parameters were calculated on a leaf area basis. Leaf area was determined in situ just prior to the gas exchange measurements by means of a portable area meter (Licor 3000 , Li-Cor, Lincoln, NE, USA).

\section{Carbon isotopic composition}

Carbon isotopic composition was determined on leaf material. Three leaves from each of the 6 trees in the different treatments were harvested on October 12. These leaves included those in which gas exchange had been measured on August 8. After determination of leaf area, the samples were oven-dried at $70^{\circ} \mathrm{C}$ for $48 \mathrm{~h}$, weighed and finely ground. Fifteen $\mathrm{mg}$ of sample material was then weighed out and combusted in special quartz vessels under a pure $\mathrm{O}_{2}$ atmosphere. The carbon was thus quantitatively converted to $\mathrm{CO}_{2}$. Relative abundances of ${ }^{13} \mathrm{C}$ and ${ }^{12} \mathrm{C}$ were determined using a mass spectrometer (Finigan Mat). The results are expressed in terms of the conventional $\delta \%$ notation, according to the relation (Farquhar et al, 1989) :

$$
\delta=R_{\mathrm{s}} / R_{\mathrm{b}}-1
$$

where $R_{\mathrm{s}}$ and $R_{\mathrm{b}}$ refer to ${ }^{13} \mathrm{C} /{ }^{12} \mathrm{C}$ ratio in the sample and in the Pee Dee Belemnite standard (PDB), respectively.

\section{RESULTS}

\section{Microclimate, growth and gas exchange}

Gas exchange measurements were made on 5 sunny days from July 11 to August 8 with a photosynthetic photon flux density (lp) of $\approx 1400 \mu \mathrm{mol} \mathrm{m}-2 \mathrm{~s}^{-1}$ in treatment $C$ (full sunlight) (fig 3). Air temperature (control treatment) increased progressively from $22.0^{\circ} \mathrm{C}$ on July 11 to $34^{\circ} \mathrm{C}$ on August 1 and then decreased to $27^{\circ} \mathrm{C}$ on August 8. Leaf-to-air water vapour concentration $(\Delta W)$ presented similar time changes with extreme values of $\approx 14 \mathrm{~Pa} \mathrm{KPa}^{-1}$ and 34 $\mathrm{Pa} \mathrm{KPa}^{-1}$. In both $\mathrm{L}$ and $\mathrm{S}$ treatments $I_{\mathrm{p}}$ was approximately half that in $C$, except on August 8 when $I_{p}$ was identical in all treatments. The frequency distribution of $I_{p}$ in the different treatments is given in figure 4 .

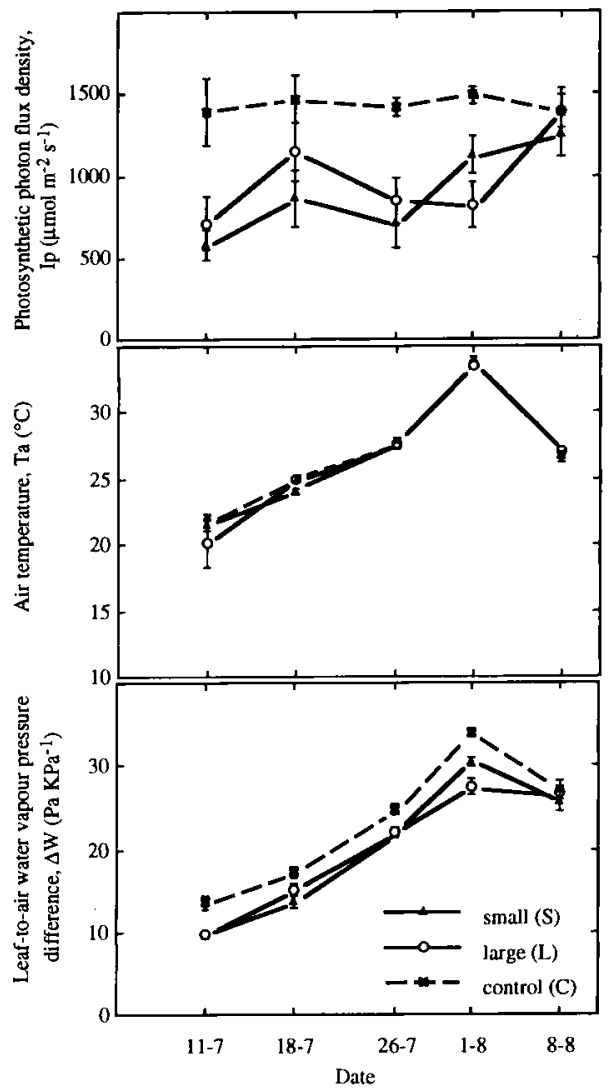

Fig 3. Photosynthetic photon flux density $\left(I_{p}\right)$, leaf-to-air water vapour concentration difference $(\Delta W)$ and air temperature $\left(T_{a}\right)$ in the 3 treatments at the different dates of gas exchange measurements. Measurements were made from $11: 30$ am to $1: 30 \mathrm{pm}$. Mean values $\pm 1 \mathrm{SEM}, n=$ 12. 
For treatment $\mathrm{C}$ a monomodal distribution was observed with a modal interval 1500 $1700 \mu \mathrm{mol} \mathrm{m}-2 \mathrm{~s}^{-1}$. For the $L$ and $S$ treatments bimodale distribution were observed, modal intervals being 250-500 and $1250-1500 \mu \mathrm{mol} \mathrm{m} \mathrm{m}^{-2} \mathrm{~s}^{-1}$. No significant differences were noticed between treatments for $T_{\mathrm{a}}$, whereas $\Delta W$ was $\approx 3-4$
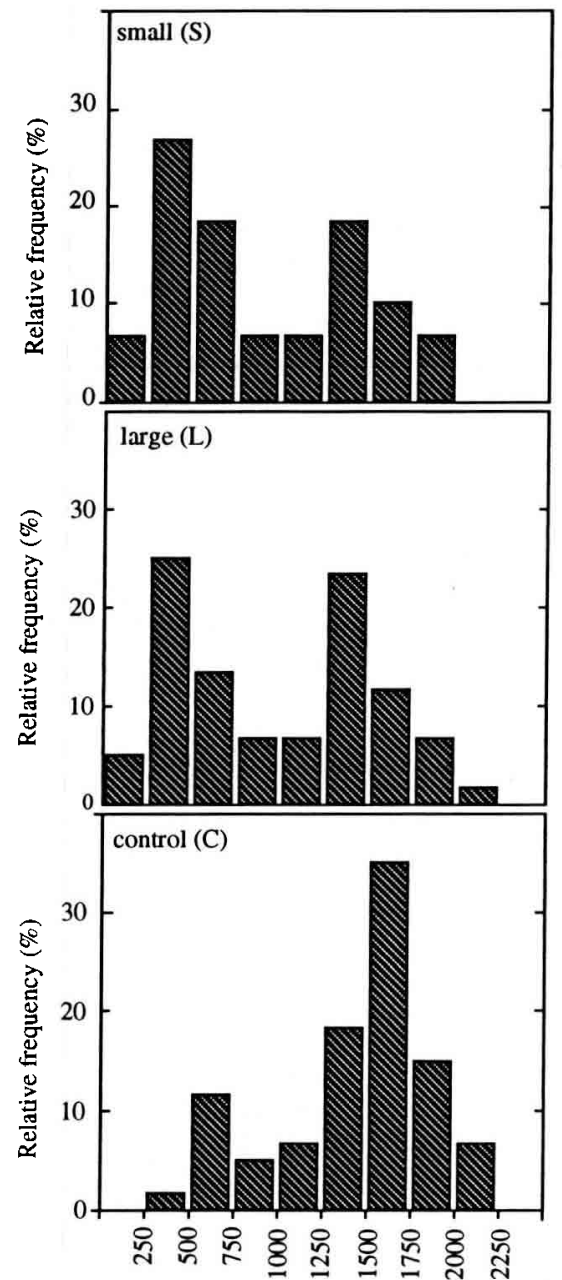

Photosynthetic photon flux density, $1_{p}\left(\mu \mathrm{mol} \mathrm{m} \mathrm{m}^{-2} \mathrm{~s}^{-1}\right)$

Fig 4. Frequency distribution of photosynthetic photon flux density $\left(l_{p}\right)$ in the 3 treatments. Measurements were made from 11:30 am to $1: 30$ pm.
$\mathrm{Pa} \mathrm{KPa}-1$ lower in the sheltered treatments as compared with treatment $C$. These between-treatment differences were associated with differences in leaf temperature $\left(T_{1}\right)$, whereas water vapour concentration in the air was identical in all treatments (data not shown).

At the end of the growing season (beginning of October) trees of treatments $\mathrm{L}$ and $S$ were taller than those of treatments C (table I), but root collar diameter and production of biomass were higher in the latter treatment. There was no significant treatment effect on root/shoot biomass ratio.

Carbon dioxide assimilation rate $(A)$ in the $C$ treatment showed a slight decrease from 18 to $13 \mu \mathrm{mol} \mathrm{m} \mathrm{m}^{-2} \mathrm{~s}^{-1}$ over the measurement period (fig 5). Except on August 8, $A$ was $\approx 5 \mu \mathrm{mol} \mathrm{m} \mathrm{m}^{-2} \mathrm{~s}^{-1}$ lower in treatments $L$ and $S$ than in $C$. This difference was not only attributable to higher $l_{p}$ values in treatment $C$, but was also linked to a higher assimilation capacity in this treatment since in saturating light conditions $\left(I_{\mathrm{p}}>1000 \mu \mathrm{mol} \mathrm{m}{ }^{-2} \mathrm{~s}^{-1}\right) A$ was $\approx 4.2 \mu \mathrm{mol}$ $\mathrm{m}^{-2} \mathrm{~s}^{-1}$ higher in treatment $C$ than in the other treatments (fig 6). Leaf conductance for water vapour diffusion ( $g$ ) decreased progressively during the measurement period in all treatments (fig 5). With the exception of July 11 , the $g$ values were identical in the $C$ and $L$ treatments, while $g$ was $\approx 80 \mathrm{mmol} \mathrm{m}^{-2} \mathrm{~s}^{-1}$ lower in $\mathrm{S}$ than in the former treatments. Leaf transpiration rates $(E)$ were highest in all treatments on August 1 (fig 5). Between-treatment differences, similar to those for $g$, arose for $E$. Intrinsic instantaneous water-use efficiency $(\mathrm{A} / \mathrm{g}$ ratio) increased in the 3 treatments during the measurement period (fig 7). This parameter was highest in $C$, lowest in $L$ and intermediate values were noticed in $\mathrm{S}$. Instantaneous water-use efficiency ( $A / E$ ratio) was markedly lower in $L$ than in the 2 other treatments. 
Table I. Height, root collar diameter, biomass and root/shoot biomass ratio of the trees at the end of the growing season.

\begin{tabular}{llll}
\hline Variables & Control $(C)$ & Large $(L)$ & Small (S) \\
\hline Height $(\mathrm{cm})$ & $170 \pm 7.2^{\mathrm{b}}$ & $198 \pm 10.4^{\mathrm{a}}$ & $219 \pm 4.8^{\mathrm{a}}$ \\
Root collar diameter $(\mathrm{mm})$ & $18.5 \pm 1.6^{\mathrm{a}}$ & $15.4 \pm 0.79^{\mathrm{b}}$ & $14.9 \pm 0.47^{\mathrm{b}}$ \\
Total biomass $(\mathrm{g})$ & $182 \pm 24^{\mathrm{a}}$ & $121 \pm 13^{\mathrm{b}}$ & $135 \pm 7^{\mathrm{b}}$ \\
Toot/shoot ratio $\left(\mathrm{g} \mathrm{g}^{-1}\right)$ & $1.01 \pm 0.13^{\mathrm{a}}$ & $1.10 \pm 0.10^{\mathrm{a}}$ & $1.14 \pm 0.05^{\mathrm{a}}$ \\
\hline
\end{tabular}

Mean values followed by different letters are significantly different (Student's $t$-test, $P \leq 0.05$ ).

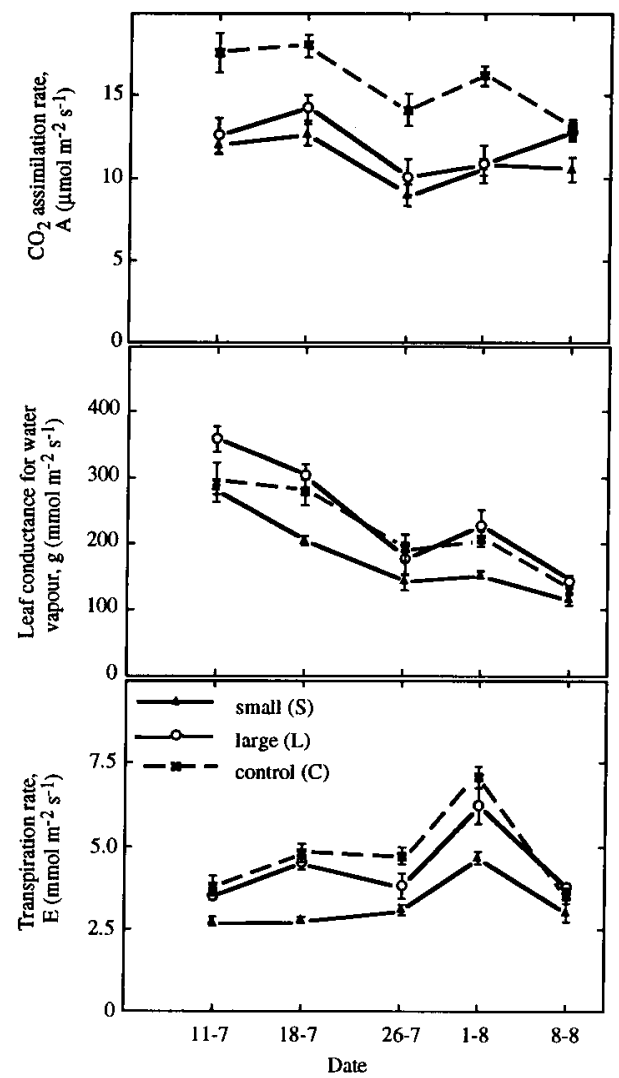

Fig 5. Carbon dioxide assimilation rate $(A)$, leaf conductance for water vapour diffusion $(g)$ and transpiration rate $(E)$ in the 3 treatments at the different dates of gas exchange measurements. Measurements were made from 11:30 am to $1: 30 \mathrm{pm}$. Mean values $\pm 1 \mathrm{SEM}$. In each treatment, measurements were made on 2 leaves of 6 different trees.

\section{Carbon isotopic composition and leaf mass per unit area}

No significant difference in relative isotopic composition $\left(\delta_{\mathrm{p}}\right)$ arose between treatments $L$ and $S$ (fig 8). Carbon isotope composition was significantly higher in the control $(-26.83 \%)$ than in treatments $S(-27.75 \%)$ and $L(-27.49 \%$ ) (table II). Leaf mass per unit area (LMA) differed significantly between the 3 treatments with $67.89,72.95$ and $101.79 \mathrm{~g} \mathrm{~m}^{-1}$ in $\mathrm{S}, \mathrm{L}$ and $\mathrm{C}$, respec-

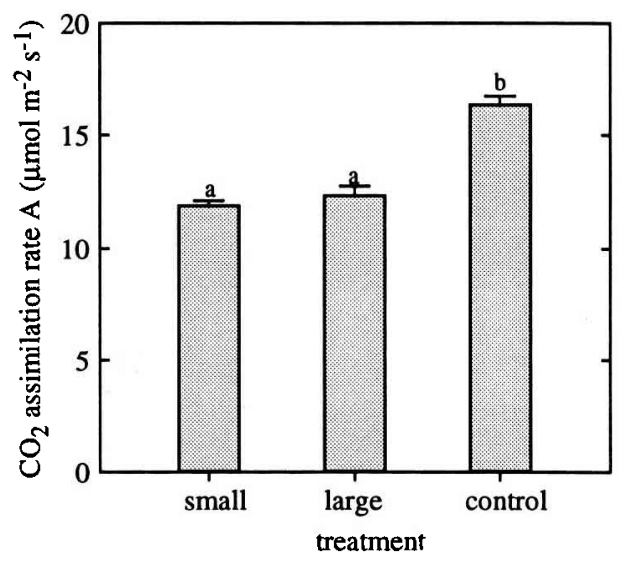

Fig 6. Light-saturated $\left(I_{\mathrm{p}}>1000 \mu \mathrm{mol} \mathrm{m} \mathrm{m}^{-2} \mathrm{~s}^{-1}\right)$ carbon dioxide assimilation rate $(A)$ in the different treatments. Data of the different dates were pooled. Mean values \pm 1 SEM. 


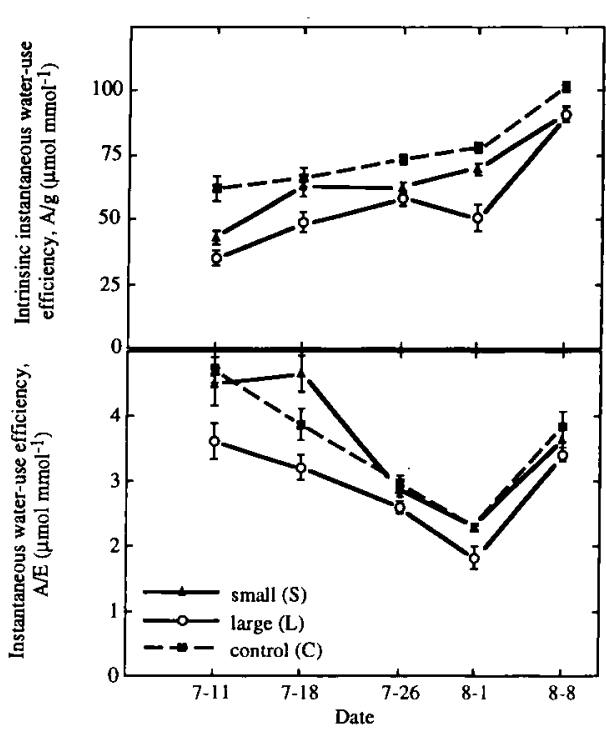

Fig 7. Intrinsic instantaneous water-use efficiency ( $A / g$ ratio) and instantaneous water-use efficiency (AVE ratio) in the 3 treatments at the different dates of gas exchange measurements. Measurements were made from 11:30 am to $1: 30 \mathrm{pm}$. Mean values $\pm 1 \mathrm{SEM}$. In each treatment, measurements were made on 2 leaves of 6 different trees.

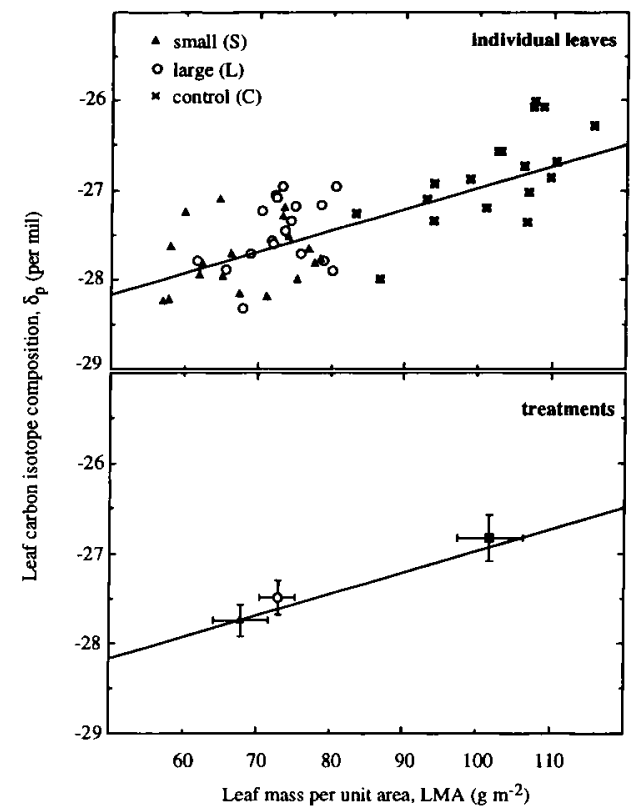

Fig 8. Leaf carbon isotopic composition $\left(\delta^{13} \mathrm{C}\right)$ in relationship with leaf mass per unit area. Data points are individual leaf values (lower part) and mean values per treatment \pm 1 SEM (upper part). Regression lines are for individual leaves in both pictures; $Y=2.61210-2 X-29.47, r=$ $0.76, n=54$.

Table II. Relative isotope composition $\left(\delta_{\mathrm{p}}\right)$, and $A / g$ ratio calculated from equation [5].

\begin{tabular}{lccc}
\hline Variables & Control (C) & Large (L) & Small (S) \\
\hline$\delta_{\text {palculated } A / g\left(\mu \mathrm{mol} \mathrm{mmol}^{-1}\right)}$ & $\begin{array}{c}-26.83 \mathrm{a} \\
64.3\end{array}$ & $\begin{array}{c}-27.49 \mathrm{~b} \\
57.6\end{array}$ & $\begin{array}{c}-27.75^{\mathrm{b}} \\
54.9\end{array}$ \\
\hline
\end{tabular}

Mean value of $\delta_{\mathrm{p}}$ followed by different letters are significantly different (Student's t-test, $P \leq 0.05$ ).

tively. There was a significant positive correlation between $\delta_{\mathrm{p}}$ and $L M A$ both at the treatment and individual plant level (fig 8).

\section{DISCUSSION}

Climatic parameters (mainly $I_{p}$ and $\Delta W$ differed between the control treatment and 
the 2 shelter treatments, but no significant difference arose between the 2 latter treatments (figs 3,4 ). For the leaves situated in the shaded part of the 2 types of shelters incident $I_{\mathrm{p}}$ was $\approx 30 \%$ of outside $l_{\mathrm{p}}$. Upper leaves of the sheltered plants could be exposed to full sunlight in the middle of the day. The proportion of these leaves and the duration of full sunlight exposition depended on the ratio (tree height/shelter height) and on the diameter of the shelter. Thus, in treatments $S$ and $L, l_{p}$ presented a bimodal distribution in the first mode (shaded region of the shelters) being $\approx$ $30 \%$ of the second (sunlit region of the shelters) (fig 4).

The ratio of $\mathrm{CO}_{2}$ assimilation rate $(A)$ in treatments $S$ and $L$ to that in treatment $C$ was $\approx 0.70$, which is identical to the ratio of total plant biomass at the end of the growing season (table l). Carbon dioxide assimilation rate was higher in the control treatment, not only because of elevated $l_{p}$ (figs $3,4)$ but also because of higher values of light saturated assimilation capacity (fig 6). Within mature Fagus silvatica and Quercus petraea canopies, Ducrey (1981) also reported a positive relationship between light-saturated $\mathrm{CO}_{2}$ assimilation rate and the proportion of solar radiation reaching the leaves during their ontogeny.

Leaf conductance values were lower in treatment $S$ than in treatments $L$ and $C$ (fig 5) ; however, this difference cannot be clearly ascribed to differences in microclimate parameters, for example $I_{\mathrm{p}}$ and $\Delta W$ (figs 3,4$)$. This discrepancy between gas exchange and microclimatic variables could be linked to the fact that no timeintegrated values of these 2 types of variables were assessed in this study.

Carbon isotope composition measurements of plant material can give access to time-integrated (lifetime of the measured organ) values of plant intrinsinc water-use efficiency (ratio $\mathrm{A} / \mathrm{g}$ ).
The apparent enrichment factor related to the isotopic fractionation by the photosynthesis processes may be expressed by an isotopic discrimination defined as (Farquhar et al, 1989):

$$
\Delta=\frac{\delta_{\mathrm{a}}-\delta_{\mathrm{p}}}{1+\delta_{\mathrm{p}}}
$$

where $\delta_{\mathrm{a}}$ and $\delta_{\mathrm{p}}$ refer to the isotopic compositions of air $\mathrm{CO}_{2}$ and of the photosynthetic products (ie the leaf material here), respectively. A typical value of $\delta_{\mathrm{a}}$ is currently -0.008 (Friedli et al, 1986).

According to Farquhar et al (1989), isotopic discrimination is given by:

$$
\Delta=a+(b-a) C_{1} / C_{a}
$$

where $a$, the discrimination against ${ }^{13} \mathrm{CO}_{2}$ during diffusion into the leaf, is $0.0044 ; b$, the discrimination during carboxylation, is $0.027 ; \mathrm{C}_{\mathrm{i}}$ and $\mathrm{C}_{\mathrm{a}}\left(\mathrm{mmol} \mathrm{mol}^{-1}\right)$ are intercellular and ambient $\mathrm{CO}_{2}$ concentrations, respectively.

The diffusion of $\mathrm{CO}_{2}$ through the stomatal pores is described by:

$$
A=1.6 g\left(C_{\mathrm{a}}-C_{\mathrm{i}}\right)
$$

Combining equations [2], [3] and [4] and substituting the different coefficients by their numerical values yields:

$$
A / g \frac{\left(329+9931.2 \delta_{\mathrm{p}}\right)}{\left(1+\delta_{\mathrm{p}}\right)}
$$

Relative carbon isotopic composition $\left(\delta_{\mathrm{p}}\right)$ was less negative $(-26.83 \%)$ in the control plants than in the plants of treatments $L$ $(-27.49 \%)$ and $S(-27.75 \%)$ which corresponds to higher time-integrated values of $\mathrm{A} / \mathrm{g}$ in the former treatment (table II). Lower $\delta_{\mathrm{p}}$ values found in lower forest canopy leaves in comparison with upper leaves 
have been attributed to low relative carbon isotope composition of source $\mathrm{CO}_{2}$ in the air $\left(\delta_{\mathrm{a}}\right)$ linked to the recycling of $\mathrm{CO}_{2}$ (depleted in ${ }^{13} \mathrm{C}$ relative to atmospheric $\mathrm{CO}_{2}$ above the canopy) originating from soil respiration (Vogel, 1978 ; Medina and Minchin, 1980 ; Francey and Farquhar, 1982 ; Medina et al, 1986 ; Gebauer and Schulze, 1991). In the present study, different light regimes and associated small differences in $T_{1}$ and $\Delta W$ (fig 3 ) were not accompanied by differing $\delta_{\mathrm{a}}$ values (constant soil respiration conditions and constant height above ground) or by changes in other microclimatic factors such as air temperature or air humidity. The difference in $\delta_{\mathrm{p}}$ found between treatment $C$ and treatments $L$ and $S$ can therefore be entirely ascribed to differences in isotopic discrimination by the leaves $(\Delta$, eq [3]) which are mainly determined by the light regime. Zimmermann and Ehleringer (1990) also found a negative correlation between leaf $\Delta$ and the daily integrated values of leaf incident $I_{p}$ in a Panamanian $\mathrm{C}_{3}$ epiphytic orchid, Casatetum viridiflavum, growing on trees of a forest canopy.

The high $\delta_{\mathrm{p}}$ (and thus low $\Delta$ ) values found here in treatment $C$ could be associated with high $A$ values (figs 5,6 ) and with high $L M A$ values (fig 8) which probably reflect high nitrogen contents per unit leaf area (no measurements of this parameter were made in this study).

The between-treatment differences in the $A / g$ ratio found here on a gas exchange basis (fig 7) were not totally consistent with the data obtained with the isotopic approach (table II). In particular, gas exchange data provided higher $\mathrm{A} / \mathrm{g}$ values (fig 7 ) - linked to lower $g$ values (fig 5 ) - in treatment $S$ than in treatment $L$, whereas isotopic data also provide higher $A / g$ values in treatment $S$ than in treatment $L$, whereas isotopic data also provide higher $A / g$ values in treatment $C$ but identical Alg values in treatments $L$ and $S$ (table II). This discrepancy might be attributed to the dif- ference in time integration scale between the 2 approaches (ie a better integrative value of the isotopic approach).

The close positive correlation found between $\delta_{\mathrm{p}}$ and $L M A$ (fig 8) at the individual leaf level shows that $L M A$, a readily measurable parameter, is not only a relevant parameter for understanding and modelling the spatial structure of $\mathrm{CO}_{2}$ assimilation in plant canopies (Aussenac and Ducrey, 1977 ; Ducrey, 1981 ; Oren et al, 1986) but can also be used for understanding and modelling water-use efficiency of canopies.

In conclusion, in this study we have simulated aerial neighbourhood relationships between young Prunus avium trees and an accompanying vegetation in the absence of water vapour source constituted by the transpiration of the accompanying vegetation. Under these conditions the height growth of young trees was improved which may be of interest from a practical point of view. However, the trees grown without shelters were characterized by a higher biomass production, which was associated with higher $A$ values than in the trees grown with shelters. Thus there was no positive effect of lateral shading on biomass growth. The control trees were also characterized by higher water-use efficiency than the sheltered trees.

\section{ACKNOWLEDGMENTS}

The authors wish to thank $M$ Pitsch and $L$ Wehrlen (INRA Nancy) for their technical assistance and AM Chiara (Centre de Recherches Geodynamiques, Thonon-Les-Bains) for the isotopic measurements. They are grateful to $M$ Dixon (INRA, Nancy) for reviewing the manuscript.

\section{REFERENCES}

Aussenac G, Ducrey M (1977) Étude bioclimatique d'une futaie feuillue (Fagus sylvatica $L$ et Quercus sessiliflora Salisb) de l'est de la 
France. I. Analyse des profils microclimatiques et des caractéristiques anatomiques et morphologiques de l'appareil foliaire. Ann Sci For 34 (4), 265-284

Aussenac G, Ducrey M (1978) Étude de la croissance de quelques espèces forestières cultivées à différents niveaux d'éclairement et d'alimentation hydrique. In : $103^{\circ}$ Congr Mondia/ Soc Savantes. Nancy, Sciences I, 105-117

Collet C, Frochot H (1992) Effet d'un abri latéral artificiel sur le développement de jeunes merisiers (Prunus avium $L$ ) installés en pépinière. Rev For Fr 44 (No sp), 85-89

Ducrey M (1981) Étude bioclimatique d'une futaie feuillue (Fagus silvatica $L$ et Quercus sessiliflora Salisb) de l'est de la France. III. Potentialités photosynthétiques des feuilles à différentes hauteurs dans le peuplement. Ann Sci For 38 (1), 71-86

Farquhar GD, Ehleringer JR, Hubick KT (1989) Carbon isotope discrimination and photosynthesis. Annu Rev Plant Physiol Plant Mol Biol 40, 503-537

Francey RJ, Farquhar GD (1982) An explanation of ${ }^{13} \mathrm{C} /{ }^{12} \mathrm{C}$ variations in tree rings. $\mathrm{Na}$ ture (Lond) 297, 28-31

Friedli $H$, Lötscher $H$, Oeschger $H$, Siegenthaler U. Stauffer B (1986) Ice record of the ${ }^{13} \mathrm{C} /$ ${ }^{12} \mathrm{C}$ ratio of atmospheric $\mathrm{CO}_{2}$ in the past two centuries. Nature (Lond) 324, 237-238

Gebauer G, Schulze ED (1991) Carbon and nitrogen isotope ratios in different compartments of a healthy and a declining Picea abies forest in the Fichtelgebirge, NE Bavaria. Oecologia 87, 198-207
Gjerstad DH, Nelson LR, Dukes JH Jr, Retzlaff WA (1984) Growth response and physiology of tree seedlings as affected by weed control. In: Seedling Physiology and Reforestation Success (Duryea ML, Brown GN, eds) Martinus Nijhoft/Dr Junk W, Dordrecht, 247-257

Medina E, Minchin P (1980) Stratification of $\delta^{13} \mathrm{C}$ values of leaves in Amazonian rain forests. Oecologia 45, 377-378

Medina E, Montes G, Cuevas E, Roksandic Z (1986) Profiles of $\mathrm{CO}_{2}$ concentration and of $\delta 13 \mathrm{C}$ values in tropical rainforest of the upper Rio Negro Basin, Venezuela. J Trop Ecol 2, 207-217

Nambiar EKS (1990) Interplay between nutrients, water, root growth and productivity in young plantations. For Ecol Manage 30, 213232

Oren R, Schulze ED, Matyssek R, Zimmermann R (1986) Estimating photosynthetic rate and annual carbon gain in conifers from specific leaf weight and leaf biomass. Oecologia 70 , 187-193

Radosevich SR, Osteryoung K (1987) Principles governing plant-environment interactions. In: Forest Vegetation Management for Conifer Production (Walstad JD, Kuch PJ, eds) John Wiley and Sons Inc, NY, 105-156

Vogel JC (1978) Recycling of carbon in a forest environment. Oecol Plant 13, 89-94

Zimmermann JS, Ehleringer JR (1990) Carbon isotope ratios are correlated with irradiance levels in the Panamanian orchid Casasetum viriflavum. Oecologia 83, 247-249 